Contents lists available at Џournal IICET

JPPI (Jurnal Penelitian Pendidikan Indonesia)

ISSN: 2502-8103 (Print) ISSN: 2477-8524 (Electronic)

\title{
Pengembangan aplikasi penilaian profil kompetensi pedagogik bedasarkan matriks peta diri berbasis web
}

\author{
Ratnawati Susanto*) \\ Universitas Esa Unggul, Indonesia
}

\begin{tabular}{l} 
Article Info \\
\hline Article history: \\
Received Jun $12^{\text {th }}, 2021$ \\
Revised Jul $20^{\text {th }}, 2021$ \\
Accepted Aug $26^{\text {th }}, 2021$ \\
\hline
\end{tabular}

\section{Keyword:}

Aplikasi

Kompetensi pedagogik

Matriks peta diri

\begin{abstract}
Profil kompetensi pedagogik menjadi karakteristik kunci kemampuan guru dalam proses pembelajaran. Adanya penilaian secara berkala dan berkelanjutan merupakan kebutuhan guru sebagai individu dan organisasi sekolah agar menjadi sumber data autentik dalam pembinaan dan pengembangan profil kompetensi pedagogik yang mendukung kualitas proses dan hasil pembelajaran peserta didik. Penelitian ini dilakukan sebagai upaya pengembangan aplikasi guna memenuhi kebutuhan para guru dan sekolah dalam melakukan penilaian profil kompetensi pedagogik berdasarkan Matriks Peta Diri Berbasis Web, yang mengintegrasikan aspek pemaknaan nilai profesi, keterlibatan dengan organisasi dan strategi pengembangan kompetensi. Metode penelitian yang digunakan adalah riset dan pengembangan (R \& D). Berdasarkan pengujian diperoleh hasil bahwa aplikasi. Penilaian Profil Kompetensi Pedagogik berdasarkan Matriks Peta Diri berbasis Web memberikan hasil secara efektif dan efisien bagi para guru dan sekolah dalam melakukan penilaian secara berkala, berkelanjutan dan menyeluruh terhadap profil kompetensi pedagogik dengan pengembangan pemaknaan nilai profesi, keterlibatan dengan organisasi dan strategi pengembangan kompetensi.
\end{abstract}

(C) 2021 The Authors. Published by IICET.

This is an open access article under the CC BY-NC-SA license (https://creativecommons.org/licenses/by-nc-sa/4.0)

\section{Corresponding Author:}

Ratnawati Susanto,

Universitas Esa Unggul

Email: ratnawati@esaunggul.ac.id

\section{Pendahuluan}

Rendahnya kompetensi pedagogik guru di Indonesia menjadi permasalahan dunia pendidikan yang sangat mendasar (Ybyraimzhanov et al., 2020). Hal ini menyebabkan pengembangan kompetensi pedagogik menjadi issue strategik dalam profesi guru. Sementara penilaian secara berkala dan berkelanjutan terhadap profil kompetensi pedagogik guru belum menjadi program penilaian dan pengembangan guru pada organisasi sekolah. Penilaian profil kompetensi pedagogik menjadi ranah dalam sertifikasi guru, namun hasilnya tidak menjadi bagian pembinaan di sekolah dan sebaliknya pembinaan dan pengembangan kompetensi pedagogik belum menjadi ranah terintegrasi aygn dapat dilakukans ecara efektif dan efisien bagi guru secara individu dan sekolah.

Beberapa pertimbangan dan alasan mengapa menjadi sangat penting bagi guru dan sekolah sebagai organisasi untuk menerapkan penilaian profil kompetensi pedagogik guru secara berkala dan berkesinambungan: (1) kompetensi pedagogik merupakan kompetensi kunci Pendidikan (Irina, 2011), (2) pengembangan diri terhadap kompetensi pedagogik merupakan kebutuhan utama yang perlu dilakukan bagi guru di masa depan (Mirzagitova \& Akhmetov, 2015), (3) kompetensi pedagogik merupakan persyaratan 
dalam mengemban tugas guru (Liakopoulou, 2011), (4) kompetensi pedagogik memberikan dasar yang kokoh dalam tindakan humanis interaksi pembelajaran (Liakopoulou, 2011), (5) dibutuhkan kompetensi pedagogik dalam mengkolaborasikan pembelajaran yang berbasis pada capaian lulusan abad 21 (Tjahjono et al., 2020)

Dalam perkembangannya, kompetensi pedagogik tidak dapat menjadi kompetensi yang berdiri sendiri, tetapi sangat membutuhkan 3 aspek yang secara signifikan memberikan pola terhadap model pengembangan kompetensi pedagogik, yang mencakup karakteristik: (1) bagaimana guru dapat memaknai nilai profesi, (2) guru memiliki kemampuan keterlibatan dengan organisasi melalui integrasi visi, misi dan pekerjaan kunci, dan (3) kemampuan guru dalam strategi pengembangan kompetensi (Susanto et al., 2020). Untuk itu maka sangat dibutuhkan pengembangan aplikasi Penilaian Profil Kompetensi Pedagogik yang menyentuh ketiga aspek dan dapat digunakan guru secara individu dan organisasi sekolah secara efektif dan efisien.

Beberapa penelitian telah dilakukan untuk penilaian kompetensi pedagogik. Penelitian yang telah dilakukan oleh A.A. Salamatov adalah penilaian pada faktor-faktor pedagogical, organisasi dan kondisi pedagogikal dengan menggunakan metode qualimetric monitoring (V.G. (Salamatov et al., 2021). Penelitian lain juga dilakukan oleh pennilaian kompetensi pedagogik melalui penilaian indikator konstruk dari kompetensi mengajar guru yang mencakup kemampuan merumuskan tujuan pembelajaran, kemampuan bertanya secara pedagogik, kemampuan menggunakan teknologi informasi dan multi media, kemampuan emngevaluasi tugas dan mempresentasikan hasil penelitian (Ye et al., 2021). Penelitian lain yang dilakukan melalui kemampuan rancang bangun media pembelajaran berbasis mobile learning android dengan alat ukur keberhasilan menyentuh level reaksi, level pembelajaran, level perilaku dan level hasil (Iyatuna, 2017).

Berdasarkan permasalahan issue strategik rendahnya kompetensi pedagogik dan telah tindak lanjut dari penelitian Pengembangan Model Kompetensi Pedagogik (2019-2021) yang berbasis pada ketiga aspek pola model pengembangan kompetensi pedagogik yang telah menunjukkan hasil bahwa guru yang secara individu dan organisasi memahami matriks peta diri dari kompetensi pedagogiknya akan menunjukkan perbedaan hasil secara signifikan terhadap kompetensi pedagogiknya. (Susanto et al., 2020).

Maka penelitian ini menjadi penting untuk dilakukan dengan tujuan untuk melakukan pengembangan aplikasi Penilaian Profil Kompetensi Pedagogik bedasarkan Matriks Peta Diri sehingga aplikasi ini dapat digunakan para guru dan sekolah untuk melakukan peta diri berdasarkan matriks peta diri untuk melakukan pengembangan kompetensi pedagogik berdasarkan data autentik dengan menyentuh ketiga aspek pengembangan.

\section{Metode}

Pengembangan aplikasi Penilaian Profil Kompetensi Pedagogik bedasarkan Matriks Peta Diri dilakukan dengan menggunakan pendekatan riset dan pengembangan ( $\mathrm{R}$ \& $\mathrm{D})$. Langkah-langkah pengembangan berfokus kepada tahapan analisis kebutuhan, rancangan produk, uji coba produk dan implementasi. Adapun Langkah penelitian dan pengembangan aplikasi dapat digambarkan sebagai berikut:

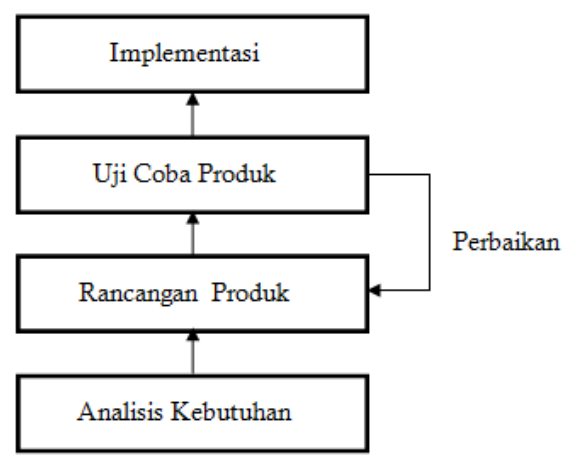

Gambar 1. Langkah Pengembangan Aplikasi

Langkah pengembangan aplikasi ini dilakukan secara ringkas dengan mengadopsi 4 tahap dari 5 tahap yang dikembangkan oleh Borg \& Gall, dan dipolakan dari tahapan awal melalui kegiatan analissi kebutuhan, rancangan produk, uji coba terbatas, revisi apabila diperlukan, dan tahapan akhir dalam kegiatan implementasi (Asiyah et al., 2021) 


\section{Hasil dan Pembahasan}

\section{Tahapan Analisis Kebutuhan}

Tahapan analisis kebutuhan perlu dilakukan dalam kaitan menggali kompetensi (Leal Filho et al., 2021) Penggalian kompetensi berdasarkan analisis kebutuhan menggambarkan profil yang dibutuhkan dari sebuah kompetensi. Pada tahapan analisis kebutuhan juga dilakukan penggalian informasi mengenai kebutuhan dari sistem yang akan dirancang, yang mencakup: data yang akan diolah, proses yang akan terlaksana, input yang akan dihasilkan, user atau pengguna yang terlibat dan fungsi. Analisis kebutuhan ini dilakukan dengan menggunakan metode wawancara dengan calon pihak pengguna atau user. Hal yang menjadi pertanyaan wawancara mencakup: (1) peta diri. Setelah dilakukan wawancara, maka dilakukan observasi untuk melihat pelaksanaan guru dan sekolah dalam melakukan proses pembelajaran dalam penerapan kompetensi pedagogik. Hal ini merupakan verifikasi terhadap data hasil wawancara.

\section{Tahapan Rancangan produk}

Rancangan produk dibuat dengan berbasis analisis kebutuhan berupa aplikasi Penilaian Profil Kompetensi Pedagogik bedasarkan Matriks Peta Diri Berbasis Web. Adapun perangkat aplikasi berbasis web ini dirancang guna memudahkan pengguna dalam pengoperasiannya. Sistem informasi dalam aplikasi berbasis web ini digambarkan dengan Diagram flow yang sebagai berikut:

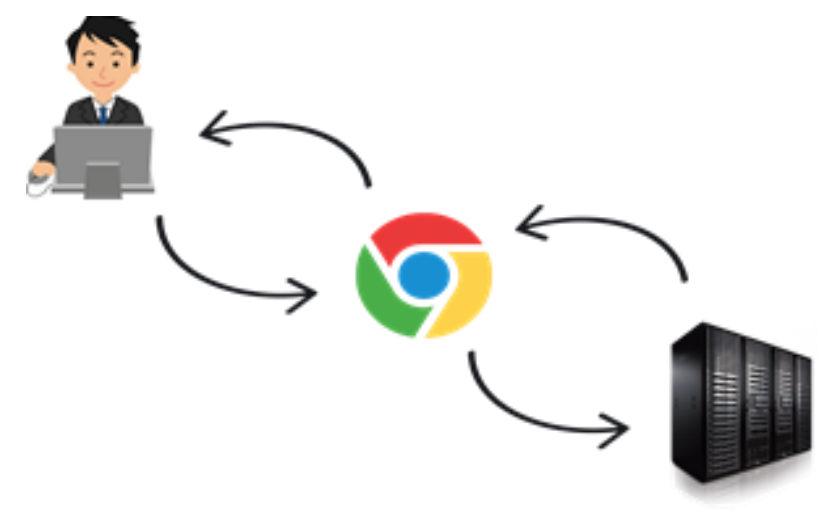

Gambar 2. Modul Aplikasi

Aplikasi berbasis web ini menggambarkan matriks peta diri yang merupakan matriks peta diri dari penentuan kesesuaian data ketiga profil baik profil karakteristik awal guru, profil keterlibatan guru dengan organisasi dan profil strategi peningkatan pengetahuan dan pendampingan kompetensi. Aplikasi ini dapat dioperasikan dengan menghubungkan website ke dalam komputer atau smart phone dan pengguna dapat mengakses informasi di dalamnya.

Tampilan aplikasi dirancang dengan halaman-halaman sebagai berikut:

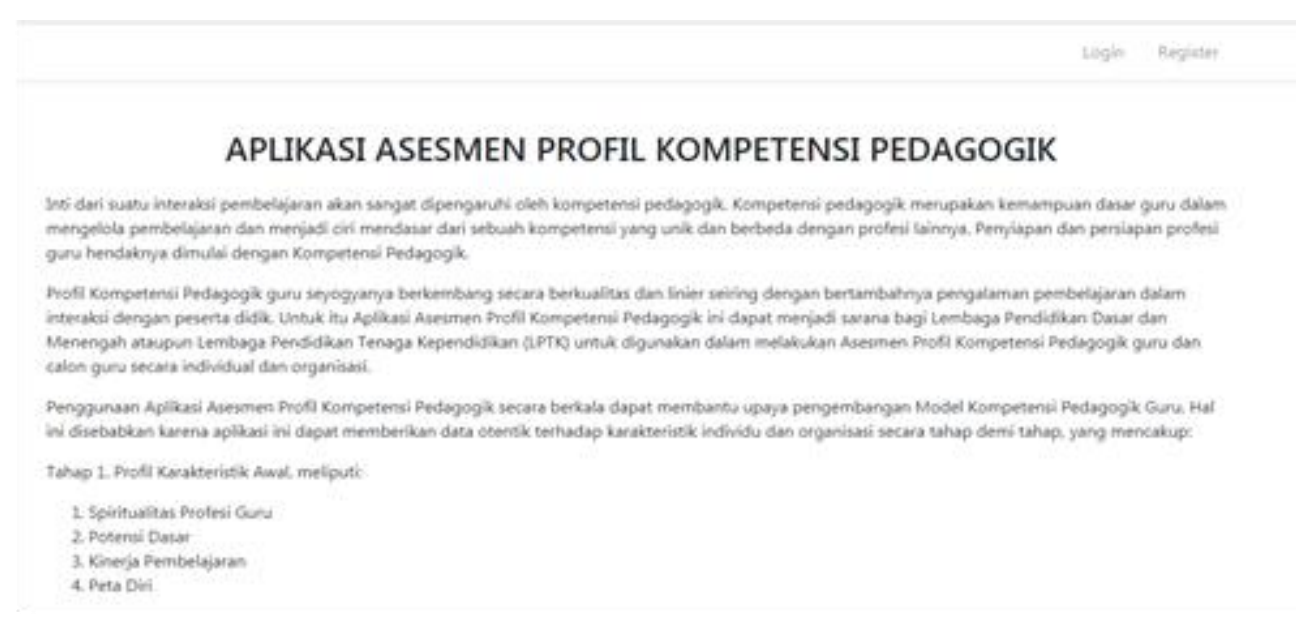

Gambar 3. Tampilan Halaman Awal 

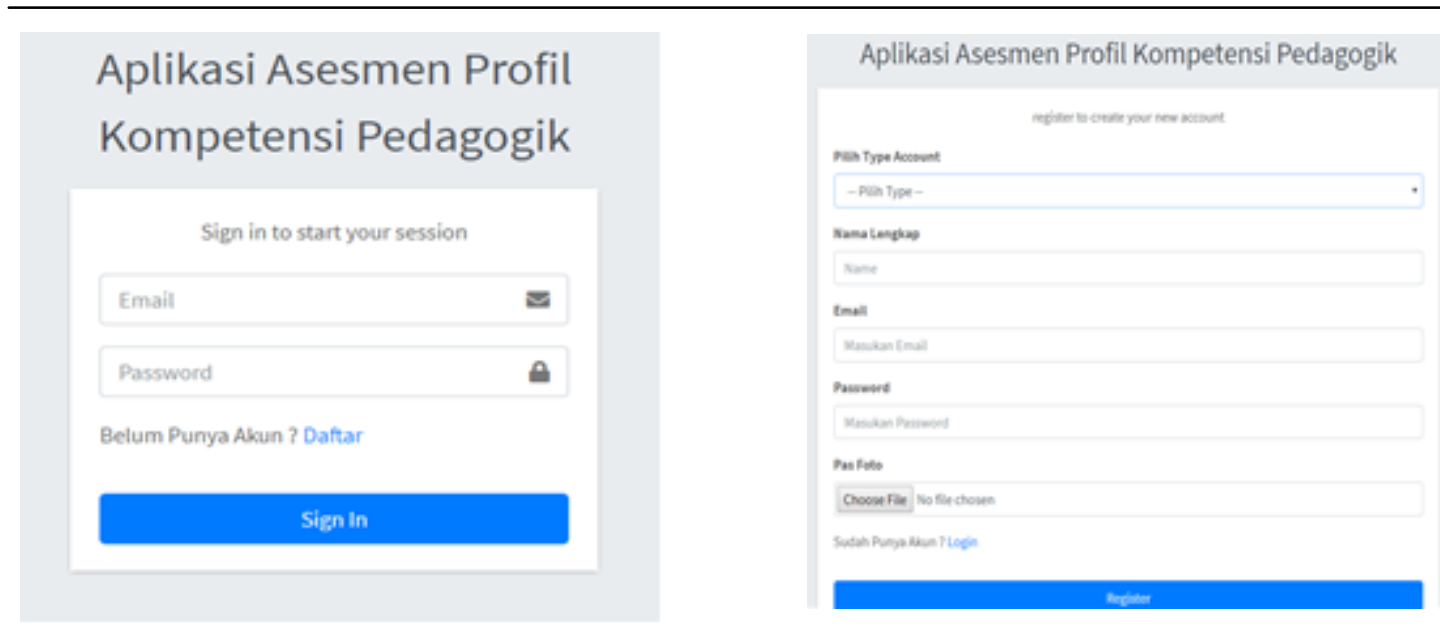

Gambar 4. Tampilan Menu Login dan Register

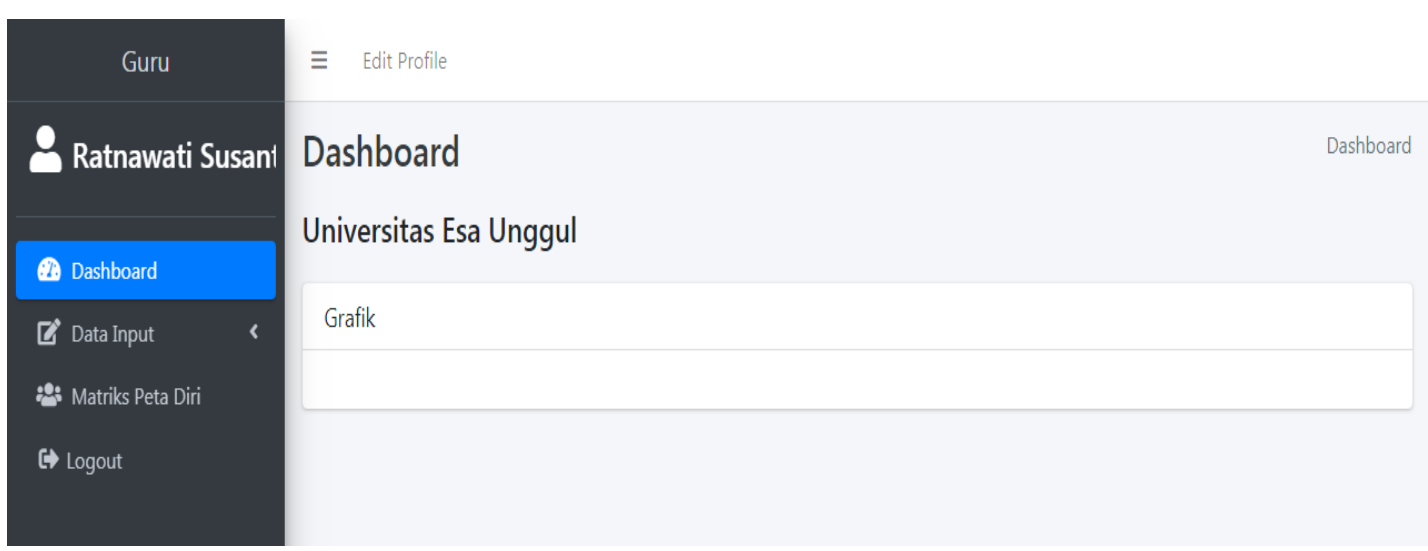

Gambar 5. Tampilan Beranda Halaman Guru (Menu Dashboard)

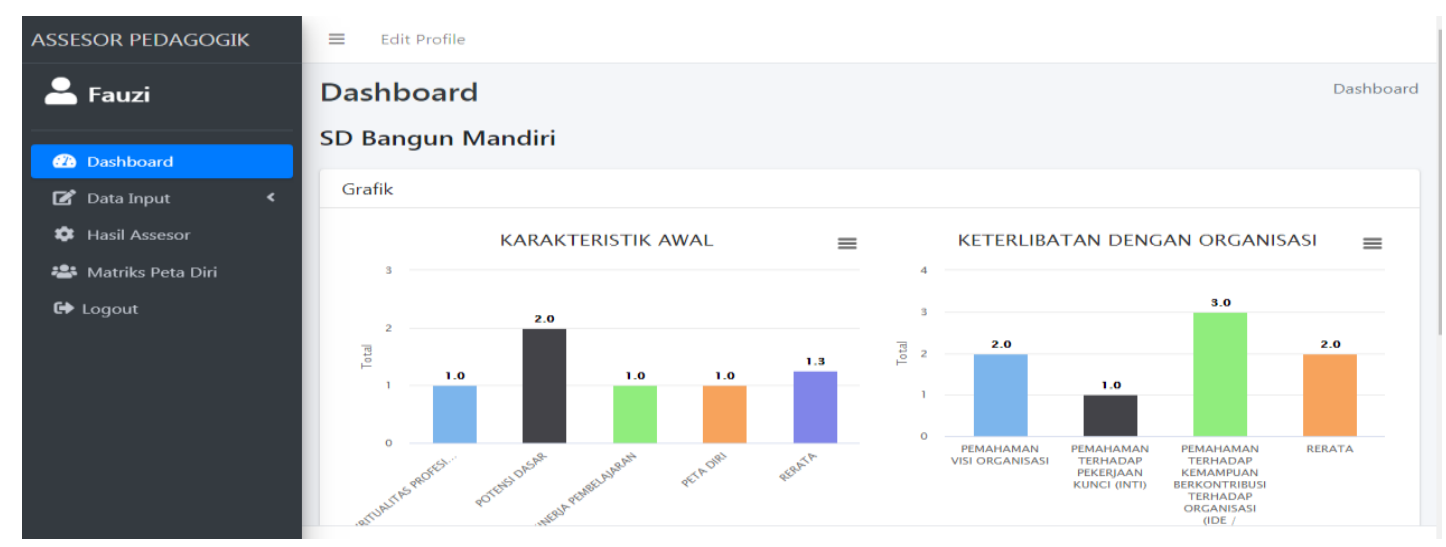

Gambar 6. Tampilan Halaman pengguna (Guru) 


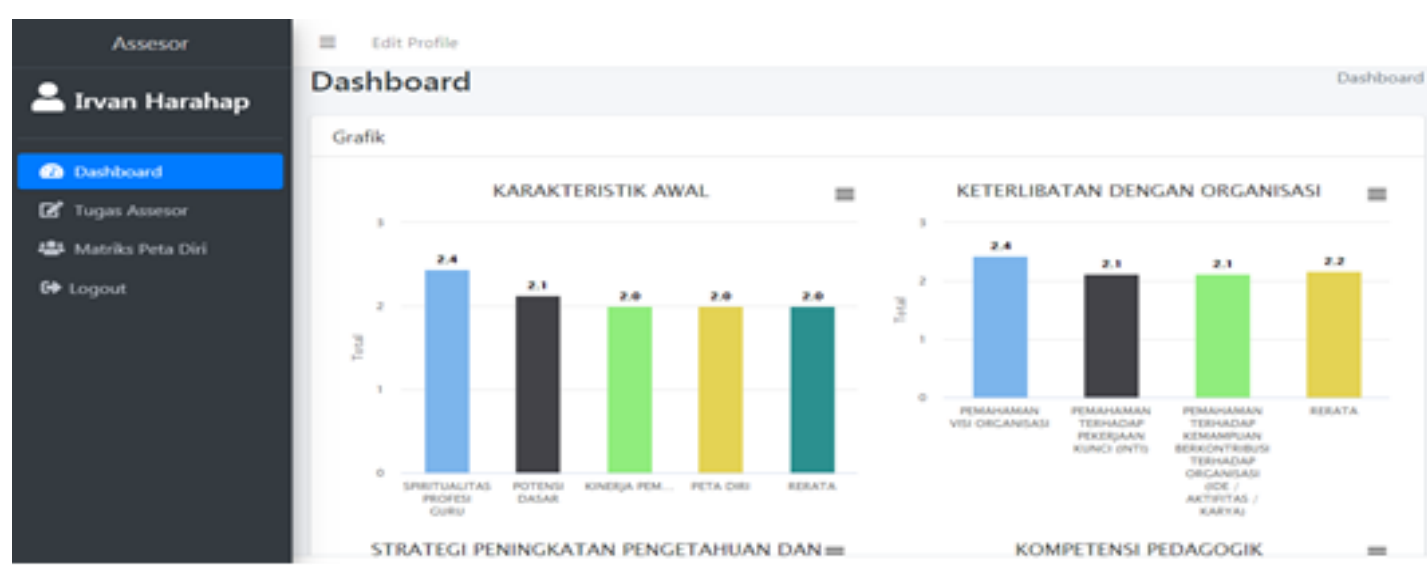

Gambar 7. Tampilan Halaman pengguna (Asesor)

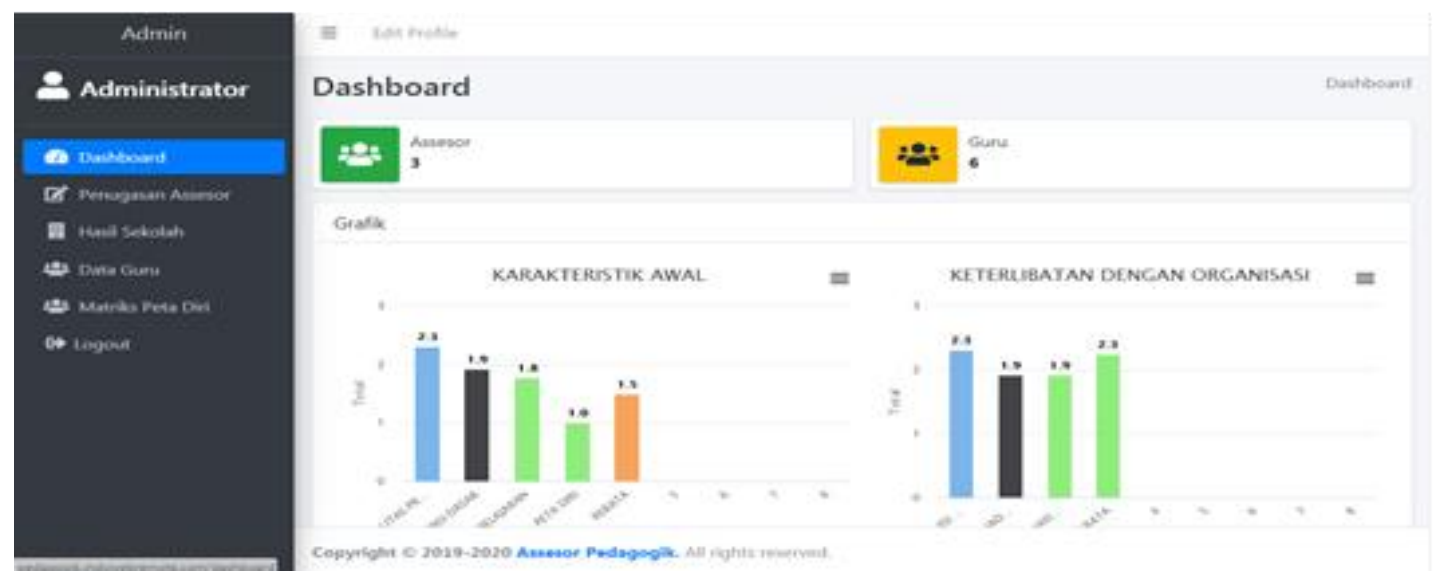

Gambar 8. Tampilan Halaman Beranda Pengguna (Admin)

Metode penilaian profil kompetensi pedagogik berdasarkan matriks peta diri pada tahap 1 profil karakteristik awal guru, di mana terdapat penentuan penilaian data karakteristik awal guru pada tiap komponennya yang terdiri dari spiritualitas profesi, potensi dasar dan kinerja pembelajaran. Penentuan pada masing-masing komponen terkait dengan data dan kesesuaian dengan metode penilaian sehingga menampilkan skor profil tertinggi 3, skor 2 cukup dan skor 1 yang berarti rendah. Pada komponen pertama dari profil karakteristik awal guru deskripsi profil skor tertinggi mencerminkan spiritualitas profesi sebagai cita-cita/ panggilan hidup, skor 2 berarti bahwa spiritualitas profesi berasal sebagai motivasi dari luar diri, dan skor terendah 1 berarti spiritualitas profesi tidaklah menggambarkan cita-cita; selanjutnya pada komponen kedua potensi dasar, profil guru menggambarkan sebagai tindakan belajar bertumbuh dan berkembang dalam kegiatan pengembangan diri baik melalui pelatihan dan berbagai kegiatan lainnya, dan penentuan profil ditandai dengan skor tertinggi 3 yang berarti mengikuti $\geq 7$ kali per tahun terakhir, skor 2 berarti mengikuti 4-6 kali per tahun terakhir, atau skor terendah 1 yang berarti $\leq 3$ kali per tahun terakhir; selanjutnya pada komponen ketiga Kinerja Pembelajaran guru menggambarkan profil kemampuan guru dalam mengelola perubahan perilaku belajar peserta didik dengan penentuan kesesuaian data dan gambaran profil skor tertinggi 3 yang berarti $\leq 10 \%$ peserta didik mengalami permasalahan perilaku belajar, skor 2 yang berarti $11-30 \%$ peserta didik mengalami permasalahan perilaku belajar, atau skor terendah 1 yang berarti $>30 \%$ peserta didik mengalami permasalahan perilaku belajar;

Pada penilaian profil kompetensi pedagogik berdasarkan matriks peta diri berbasis web pada tahap 2 keterlibatan guru dengan organisasi maka dilakukan penentuan kesesuaian data pemahaman visi organisasi, pemahaman terhadap pekerjaan kunci (inti) dan pemahaman terhadap kemampuan berkontribusi terhadap organisasi, di mana skor 3 menggambarkan skor profil tertinggi, skor 2 menggambarkan profil cukup, dan skor 1 menggambarkan profil yang rendah.

Pada penentuan kesesuaian data profil kompetensi pedagogik pada tahap 3 profil strategi peningkatan pengetahuan dan pendampingan model kompetensi pedagogik, terdapat lima komponen yang termuat di dalamnya, yaitu: komponen pertama strategi peningkatan pengetahuan pedagogik yang mewakili data kemampuan guru dalam meningkatkan pengetahuan yang mencakup 5 strategi: (a) pengetahuan pedagogik, (b) kemampuan reflektif, (c) kecerdasan emosional, (d) pola komunikasi isntruksional, dan $€$ kompetensi 
pedagogik dan gambaran profil dengan skor 3 sebagai skor tertinggi yang menggambarkan kemampuan guru dalam menerapkan $>2$ strategi secara konsisten, faktual dan berdampak pada kinerja pembelajaran, skor 2 apabila profil guru menunjukkan kemampuan menerapkan 1-2 strategi secara konsisten, faktual dan berdampak pada kinerja pembelajaran, atau skor 1 yang menunjukan bahwa profil guru dalam menerapkan strategi tidak secara konsisten, tidak faktual dan tidak berdampak pada kinerja pembelajaran;

Selanjutnya adalah penentuan data sebagai penilaian profil Kompetensi pedagogik berdasarkan matriks peta diri berbasis web.Matriks peta diri merupakan sebuah peta yang digambarkan dalam matriks untuk menunjukkan posisi kemampuan potensi dan kinerja individu manusia (Hartley III \& Jobson, 2021). Matriks peta diri yang digunakan dalam aplikasi berbasis web ini merupakan penyatuan hasil dari profil karakteristik awal guru, profil keterlibatan guru dengan organisasi, dan profil strategi peningkatan pengetahuan dan pendampingan guru (Susanto et al., 2021). Rancangan pola Talent Search matriks dibagi ke dalam 9 kuadran dan dengan tiga kategori pertemuan potensi diri dan kinerja pembelajaran, yaitu: $(3,3),(3,2),(2,3)$; sementara pada skor 2 adalah pertemuan potensi diri dan kinerja pembelajaran, yaitu: $(3,1),(2,2)$ dan $(1,3)$; dan skor 1 sebagai skor terendah dengan pertemuan potensi diri dan kinerja pembelajaran, yaitu: $(1,1),(2,1)$, dan $(1,2)$, di mana menu matrik peta diri juga dilengkapi dengan grafik, rekapitulasi profil kompetensi pedagogik.
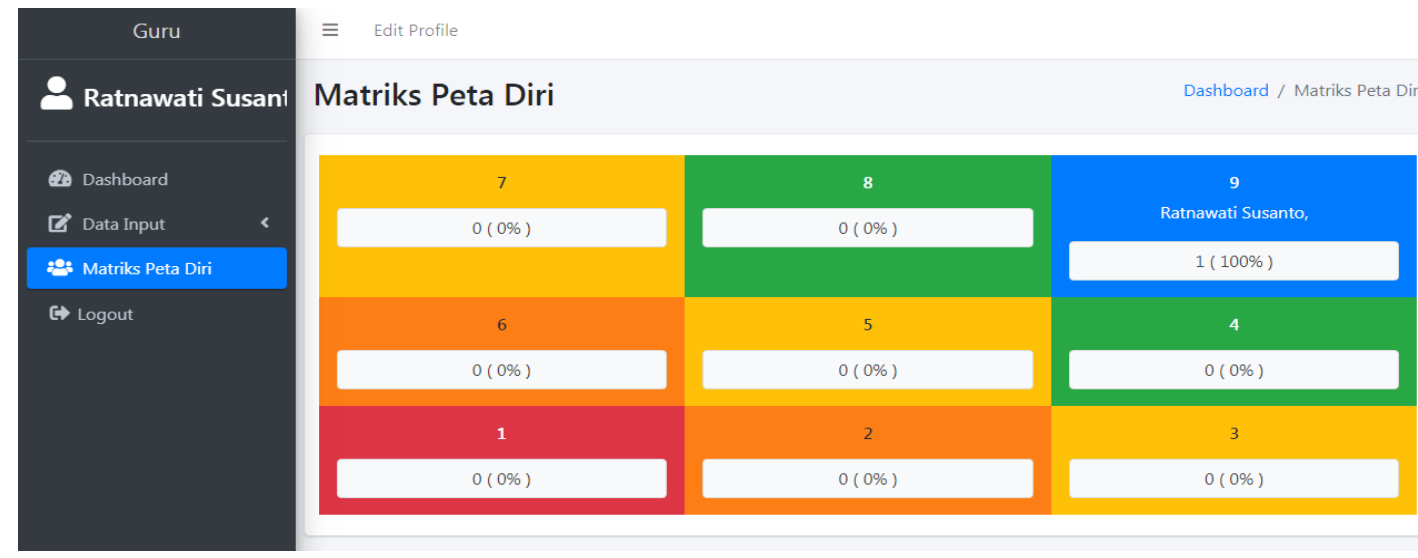

\section{Gambar 9. Matriks Peta Diri}

Hasil penilaian yang ditampilkan sistem dalam matriks peta diri ini menjadi data autentik informasi dan rekomendasi secara individual dan sekolah dalam penilaian profil kompetensi pedagogik, penilaian kemajuan profil kompetensi pedagogik dan komitmen dan perencanaan untuk pengembangan profil kompetensi pedagogik.

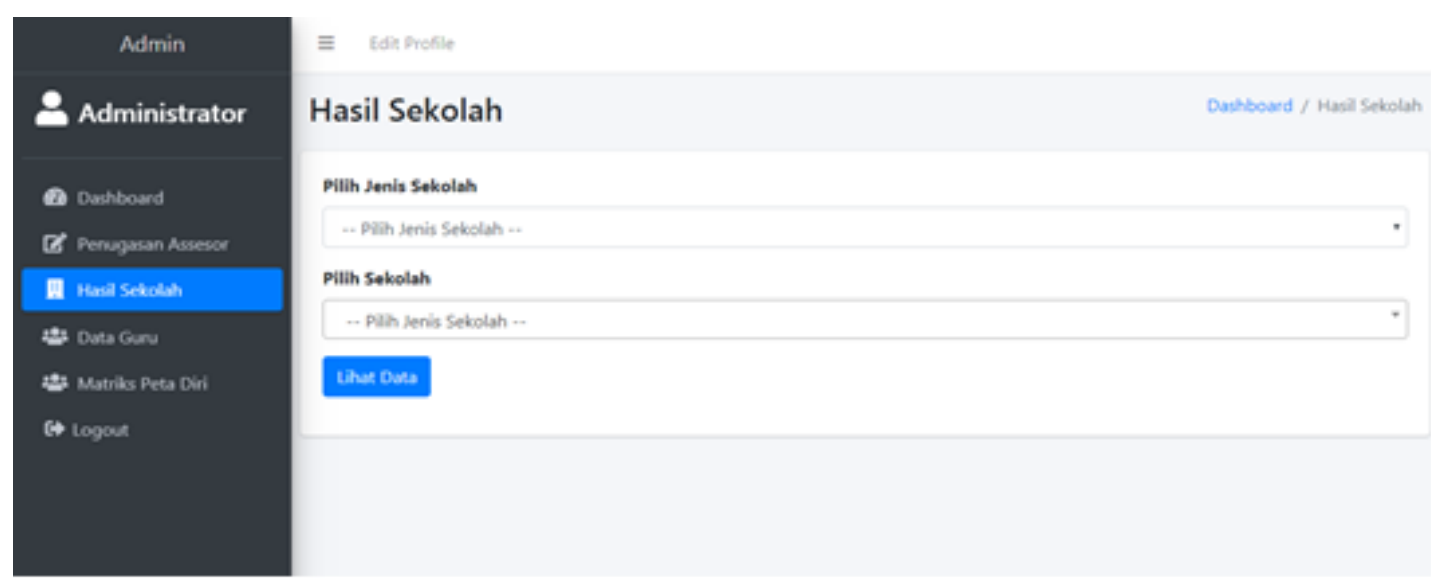

Gambar 10. Menu Data Autentik Hasil Sekolah

Profil kompetensi pedagogik berdasarkan matriks peta diri berbasis web menunjukkan penilaian profil tingkat kompetensi guru dan rekomendasi konsistensi tidaknya setiap tahapan profil dari tahap 1, 2 dan 3 dengan tingkat konsistensi Baik jika jumlah konsistensi 3, cukup jika jumlah konsistensi 2 dan kurang jika jumlah konsistensi 1 dan guru dinyatakan memiliki profil kompetensi apabila memiliki jumlah konsistensi 3 dan dinyatakan tidak kompeten apabila memiliki jumlah konssitensi $<3$. Pada rekapitulasi profil kompetensi ini maka akan dinyatakan hasil akhir rekomendasi profil kompetensi pedagogik guru sebagai berkompeten ataukah tidak berkompeten. 
Hasil penilaian setiap tahapan dan komponen dalam bentuk skor dan mutu beserta deskripsi mutu serta rekapitulasi dan rekomendasi profil kompetensi pedagogik sehingga mempermudah guru sebagai pengguna secara individual dan sekolah dalam pemetaan profil kompetensi pedagogik, mengukur kemajuan profil kompetensi pedagogik dan komitmen dan perencanaan untuk pengembangan profil kompetensi pedagogik.

Selanjutnya dilakukan tahapan rancangan produk. Rancangan produk dilakukan dengan mengintegrasikan rancangan konten aplikasi berupa modul aplikasi, menu aplikasi dan penggunaan aplikasi. Modul aplikasi mencakup konten asesmen profil kompetensi pedagogik yang terdiri dari 3 tahap : Elemen tahap 1: Profil karakteristik Awal, Elemen tahap 2: Profil keterlibatan dengan organisasi, dan Elemen tahap 3: Profil strategi peningkatan pengetahuan dan pendampingan model kompetensi pedagogik. Hasil penilaian digambarkan dalam: rekapitulasi asesmen profil kompetensi pedagogik, matriks peta diri, deskripsi profil.

\section{Tahapan Uji Coba Produk}

Tahapan uji coba produk dilakukan setelah produk dibuat dengan melibatkan tim ahli sebagai evaluator, yang terdiri dari ahli materi, ahli media, kepala sekolah, guru dan administrasi sekolah. Aspek evaluasi materi mencakup konten isi/materi, penggunaan Bahasa/kalimat, penyajian menu aplikasi dan kemudahan penggunaan. Skor evaluasi terdiri dari skor $1-4$, dengan kategori: skor 4 (sangat baik), skor 3 (baik), skor 2 (buruk) dan skor 1 (sangat buruk). Hasil evaluasi terhadap aspek materi adalah:

Tabel 1. Hasil Evaluasi terhadap Aspek Materi

\begin{tabular}{|c|c|c|c|}
\hline No & Aspek & Skor & Kategori \\
\hline 1 & Konten isi/materi & 4,00 & Sangat Baik \\
\hline & Bahasa/Kalimat & 3,75 & Sangat Baik \\
\hline Rata & ata Skor & 3,88 & Sangat baik \\
\hline
\end{tabular}

Sementara hasil evaluasi terhadap kelayakan media aplikasi adalah meliputi: kualitas penyajian, desain dan penampilan aplikasi. Hasil evaluasi tim ahli media adalah sebagai berikut:

Tabel 2. Hasil Evaluasi terhadap Aspek Kelayakan Media

\begin{tabular}{|c|c|c|c|}
\hline No & Aspek & Skor & Kategori \\
\hline 1 & Kualitas penyajian & 3,80 & Sangat Baik \\
\hline 2 & Desain & 3,50 & Sangat Baik \\
\hline 3 & Penampilan aplikasi & 3,75 & Sangat Baik \\
\hline \multicolumn{2}{|c|}{ Rata-rata Skor } & 3,68 & Sangat Baik \\
\hline
\end{tabular}

Evaluasi juga dilakukan kepada kepala sekolah, guru dan admin untuk melihat tingkat kemudahan dalam penggunaan aplikasi, kemanfaatan informasi dan kemudahan dalam membaca data. Hasil ditunjukkan sebagai berikut:

Tabel 3. Hasil Evaluasi terhadap Aspek Kemudahan Penggunaan

\begin{tabular}{clll}
\hline No & \multicolumn{1}{c}{ Aspek } & Skor & Kategori \\
\hline $\mathbf{1}$ & Kemudahan penggunaan aplikasi & 4,00 & Sangat Baik \\
\hline $\mathbf{2}$ & Kemanfaatan informasi & 3,80 & Sangat Baik \\
\hline $\mathbf{3}$ & Kemudahahan dalam membaca data & 4,00 & Sangat Baik \\
\hline Rata-rata Skor & 3,93 & Sangat Baik \\
\hline
\end{tabular}

Berdasarkan data tersebut, maka dapat dinyatakan bahwa aplikasi penilaian profil kompetensi pedagogik bedasarkan Matriks Peta Diri berbasis web telah memenuhi kelayakan dari aspek materi. Dari tabel 1 diperoleh data bahwa konten isi/materi berada pada aktegori sangat baik dan dari aspek Bahasa/kalimat berada pada kategori sangat baik dan secara rerata aspek isi/materi adalah sangat baik.

Hasil evaluasi yang ditunjukkan pada tabel 2 mengenai aspek kelayakan media, diperoleh data bahwa dari aspek kualitas penyajian diperoleh hasil evaluasi dalam kategori sangat baik, dalam aspek desain juga berada dalam kategori sangat baik dan demikian dalam penampilan aplikasi berada dalam kategori sangat baik. Secara rata-rata kategori aaspek kelayakan media berada dalam kategori sangat baik.

Dari tabel 3 diperoleh data evaluasi terhadap aspek kemudahan penggunaan aplikasi yang berada dalam kategori sangat baik dan demikian dalam kemanfaatan informasi berada dalam kategori sangat baik, dan demikian dalam kemudahan membaca data juga berada dalam kategori sangat baik.

Berdasarkan hasil evaluasi tim ahli dan pengguna, maka dapat dinyatakan bahwa pengembangan aplikasi penilaian profil kompetensi pedagogik bedasarkan Matriks Peta Diri berbasis web telah memenuhi kelayakan 
dari aspek materi, aspek kualitas penyajian dan aaspek kemudahan penggunaan aplikasi. Maka aplikasi ini tidak memerlukan perbaikan dan layak untuk digunakan dalam tahapan implementasi.

Dari sisi pengguna, aplikasi ini telah memberikan kemanfaatan infromasi yang berguna dalam membantu guru dan sekolah dalam penilaian profil kompetensi pedaogik baik secara individu maupun organisasi. Sejalan dengan hal ini seperti dalam penelitian Michael B. Cahapay, maka kebermanfaatan informasi dalam sebuah media dapat menumbuhkan self efficacy yang berperan tinggi dalam peningkatan kompetensi pedagogik dan secara langsung terkait dengan penggunaan aplikasi berbasis teknologi (Cahapay, 2021). Implikasi dalam hal ini adalah penilaian perlu dijadikan secara terprogram dan berkelanjutan untuk meningkatkan komitmen pengembangan kompetensi (Misra et al., 2021).

\section{Tahapan Implementasi}

Tahapan implementasi dilakukan dengan sosialisasi, pelatihan, pendampingan dan coaching. Sosialisasi merupakan tindakan dalam menginformasikan sesuatu hal (Pennington, 2021). Dalam kegiatan pengembangan ini, sosialisasi dimaksudkan sebagai tahap awal untuk memperkenalkan aplikasi dan manfaat. Selanjutnya dilakukan pelatihan untuk memberikan kemampuan praktis penggunaan aplikasi. Langkah selanjutnya adalah melakukan pendampingan terhadap pengguna, baik guru dan asesor agar dapat membaca dan memanfaatkan data sebagai dasar menilai kemajuan kompetensi, gambaran profil dan peta individu dan sekolah. Langkah lanjut dari tahapan uji coba produk adalah dilakukan coaching sebagai upaya untuk membantu para guru bertumbuh dan berkembang dengan Teknik mengorganisasikan peta diri berdasar data dan melakukan komitmen pertumbuhan dan pengembangan diri (Stokes et al., 2021; Thompson, 2021) .

\section{Simpulan}

Kesimpulan dari hasil pengembangan dan uji coba dengan metode R\&D: 1) Untuk menjawab tujuan penelitian dalam menghasilkan rancangan sistem informasi berupa pengembangan Aplikasi Penilaian $\mathrm{P}$ rofil Kompetensi Pedagogik bedasarkan; 2) Matriks Peta Diri Berbasis Web dilakukan dengan langkah tahapan analisis kebutuhan, Rancangan Produk, Uji Coba Produk dan Implementasi. Rancangan menghasilkan data yang akan diolah, proses yang akan terlaksana, input yang akan dihasilkan, user atau pengguna yang terlibat dan fungsi. Adapun konten modul aplikasi mencakup konten asesmen profil kompetensi pedagogik yang terdiri dari 3 tahap: Elemen tahap 1 Profil karakteristik Awal, Elemen tahap 2: Profil keterlibatan dengan organisasi, Elemen tahap 3: Profil strategi peningkatan pengetahuan dan pendampingan model kompetensi pedagogik dan memuat hasil berupa Rekapitulasi asesmen profil kompetensi pedagogik, Matriks peta diri, dn Deskripsi Profil; 3) Metode penilaian profil kompetensi pedagogik berdasarkan matriks peta diri berbasis web ini merupakan sangat mudah digunakan, lebih baik, mudah diterapkan dan dapat digunakan setiap pihak pengguna guru, asesor dan admin yang berfungsi sebagai pemetaan dan memberikan informasi dan rekomendasi secara individual dan sekolah dalam pemetaan profil kompetensi pedagogik, mengukur kemajuan profil kompetensi pedagogik dan komitmen dan perencanaan untuk pengembangan profil kompetensi pedagogik.

\section{Referensi}

Asiyah, Sapri, J., Novitasari, N., Saregar, A., Topano, A., Walid, A., \& Tamrin Kusumah, R. G. (2021). Construction Ethnoscience-Based Learning Environment Material in Scientific Knowledge. IOP Conference Series: Earth and Environmental Science, 1796(1). https://doi.org/10.1088/1742$6596 / 1796 / 1 / 012034$

Cahapay, M. B. (2021). Technological pedagogical knowledge self-efficacy and continuance intention of Philippine teachers in remote education amid COVID-19 crisis. Journal of Pedagogical Research, 5(3), 6879. https://doi.org/10.33902/jpr.2021370614

Hartley III, D. S., \& Jobson, K. O. (2021). Introduction: Humans and Their Matrix. In Cognitive Superiority. https://doi.org/10.1007/978-3-030-60184-3_1

Irina, A. (2011). Pedagogical Competences - The Key to Efficient Education. International Online Journal of Educational Sciences, 3(2), 411-423.

Iyatuna, T. (2017). TARB IYATUNA, Vol. 8 No. 2 Desember, 2017 94. 8(2), 94-103.

Leal Filho, W., Levesque, V. R., Salvia, A. L., Paço, A., Fritzen, B., Frankenberger, F., Damke, L. I., Brandli, L. L., Ávila, L. V., Mifsud, M., Will, M., Pace, P., Azeiteiro, U. M., \& Lovren, V. O. (2021). University teaching staff and sustainable development: an assessment of competences. Sustainability Science, 16(1), 101-116. https://doi.org/10.1007/s11625-020-00868-w

Liakopoulou, M. (2011). Teachers' Pedagogical Competence as a Prerequisite. European Journal of Education, $46(4), 474-488$. 
Mirzagitova, A. L., \& Akhmetov, L. G. (2015). Self-development of pedagogical competence of future teacher. International Education Studies, 8(3), 114-121. https://doi.org/10.5539/ies.v8n3p114

Misra, S., Iobst, W. F., Hauer, K. E., \& Holmboe, E. S. (2021). The Importance of Competency-Based Programmatic Assessment in Graduate Medical Education. Journal of Graduate Medical Education, 13(2), 113-119. https://doi.org/10.4300/JGME-D-20-00856.1

Pennington. (2021). Concepts in Occupational Socialization Theory. Journal of Curriculum and Teaching Methodology, 4, 1-3. https://doi.org/10.23977/curtm.2021.040101

Salamatov, A. A., Belevitin, V. A., Gafarova, E. A., \& Gordeeva, D. S. (2021). Qualimetric Assessment of Pedagogical Factors in the Formation of Professional Environmental and Economic Competence of $\begin{array}{lllll}\text { University Graduates. } & \text { SHS } & \end{array}$ https://doi.org/10.1051/shsconf/202111003012

Stokes, P., Fatien Diochon, P., \& Otter, K. (2021). "Two sides of the same coin?" Coaching and mentoring and the agentic role of context. Annals of the New York Academy of Sciences, 1483(1), 142-152. https://doi.org/10.1111/nyas. 14316

Susanto, R., Agustina, N., Rozali, Yuli Azmi, M., Tjahjono, B., \& Rosyid, A. (2021). Analysis of Primary School Teachers 'Pedagogical Competencies through Talent Search Matrix. Psychology and Education, $57(8), 360-369$.

Susanto, R., Agustina, N., \& Rozali, Y. A. (2020). Analysis of the Application of the Pedagogical Competency Model Case study of Public and Private Primary Schools in West Jakarta Municipality , DKI Jakarta Province ). Elementary Education Online, 19(3), 167-182. https://doi.org/10.17051/ilkonline.2020.03.114

Thompson, R. (2021). Coaching and Mentoring with Metaphor. International Journal of Evidence Based Coaching and Mentoring, 212-228. https://doi.org/10.24384/4sve-8713

Tjahjono, Susanto, \& Yulhendri. (2020). The Development of Collaborative Learning in The Frame work of Learning Developmnet HE 4.0. International Journal of Science, Technology \& Management, 1(4), 298-305. https://doi.org/10.46729/ijstm.v1i4.95

Ybyraimzhanov, K., Zhanatbekova, N., Danikeeva, A., Abdykerimova, E., \& Julkybekova, G. (2020). Pedagogical competence as means of developing the professional potential of the teacher. Talent Development and Excellence, 12(1), 294-307.

Ye, J., Mi, S., \& Bi, H. (2021). Constructing core teaching competency indicators for secondary school science teachers in China. Journal of Baltic Science Education, 20(3), 389-406. https://doi.org/10.33225/jbse/21.20.389 